\title{
Sciendo
}

DOI: $10.2478 /$ aa-2019-0011

\section{A voyage from Apollonian Munich to Dionysian Venice in Thomas Mann's} Death in Venice

Nilay Erdem Ayyıldız

Nilay Erdem Ayyıldız is an English Language and Literature graduate of Hacettepe University. She obtained her MA in the same subject at Firat University, where she is currently teaching. She obtained her PhD from Atılım University, Department of English Language and Literature, with a full scholarship from TUBITAK (The Scientific and Technological Research Council of Turkey). Her dissertation was on the representation of colonial ideology in $19^{\text {th }}$-century British children's adventure novels. It was published as a book entitled British Children's Adventure Novels in the Web of Colonialism by Cambridge Scholars Publishing in September 2018. Her chapter examining British gendered imperial politics in Kipling's Jungle Book was also published in a book entitled Language, Power and Ideology in Political Writing by IGI Global Publishing in June 2019. Her areas of interest are Victorian and children's works of literature and postcolonial and gender studies on which she has delivered conference papers and published journal articles.

Abstract: This paper explores the intersection of cities and the protagonist's ApollonianDionysian dichotomy in Thomas Mann's preeminent semi-autobiographical novella Death in Venice (1912) within the cultural and contextual considerations of $20^{\text {th }}$-century Munich and Venice. The protagonist Gustav von Aschenbach's oscillation between artistic appreciation and sensual desire is personified by the contrasts Munich draws as a city of enlightenment against Venice which is the city of sensuality and freedom. The article indicates that the narrator associates Nietzsche's conceptions of the Apollonian and Dionysian parts of human nature with Venice, which acts as a character providing crucial elucidation in regards to the mental state of the protagonist throughout the novella. Thus, the study sheds light upon the symbolic voyage Aschenbach embarks upon - from Apollonian nature to Dionysian nature; from Munich to Venice, where his predominating Dionysian nature burst out through the city, luring him to his own demise.

\section{Introduction}

In regard to art, Nietzsche mentions two principles called the Apollonian and the Dionysian. He regards sculpture as Apollonian while music is Dionysian. For him, tragedy is born out of the union of these two principles as the ultimate expression of art, life and culture. He states: "the intricate relation of the Apollonian and the Dionysian in tragedy may really be 
symbolised by a fraternal union of the two deities: Dionysus speaks the language of Apollo; and Apollo, finally the language of Dionysus" (1992, p. 130). Stating that tragedy, which is taken as the highest form of art, died with the Greek comedy playwright Euripides as he paralysed the equilibrium between the Apollonian and Dionysian principles, he posits that everything has failed to be tragedy and been nothing other than mockery since then.

Although Nietzsche applies the mentioned dichotomy to art, consideration of art as a representation of life renders an evaluation of the human being as the embodiment of the united Apollonian and Dionysian selves, though one of them presides over the other one. Named after the sun-god Apollo, the Apollonian represents beauty, self-control, perfection, rationality, order and isolation. On the other hand, the Dionysian, named after the wine-god Dionysus, stands for passion, self-forgetfulness, irrationality, chaos, intoxication and collection. Drawing attention to suffering, revealed by excessiveness of the Dionysian, Nietzsche pictures a Dionysian festival as follows: "Excess revealed itself as truth. Contradiction, the bliss born of pain, spoke out from the very heart of nature. And so, wherever the Dionysian prevailed, the Apollonian was checked and destroyed" (1992, p. 47). Accordingly, in Nietzsche's understanding, the Dionysian embodies a flow of unrestrained energy which knows no discipline nor boundaries set by the Apollonian. Thus, it draws an artist or a human being into a drunken frenzy which brings his own end. It is the Apollonian aspect that supplies him with enough strength to form the Dionysian to become creative rather than destructive. On the other hand, the Apollonian self also necessitates passion to be creative, thus it joins the Dionysian self in a coherent unity. Therefore, they balance each other as the centripetal and centrifugal forces do. Mann introduces his classicist and disciplined character to "an ascetic life" (Mundt, 2004, p. 89). Accordingly, an artist is supposed to strike a balance between his innate Apollonian and Dionysian natures to produce a qualified work as a human being needs to do so to achieve harmony in his life.

The purpose of this paper is to analyse the Dionysian Venice which acts as a character in Thomas Mann's novella Death in Venice (1912) by alluring the protagonist Gustave von Aschenbach from Munich, a city which characterizes him predominantly with the Apollonian principles.

\section{Thomas Mann and Death in Venice}

Thomas Mann (1875-1955) was a widely known German author of the $20^{\text {th }}$ century. Emphasizing psychological realism in his works, Mann took his subject matter from "the cultural and spiritual crises of Europe" and "the visible disintegration of an entire society" (Lawall, et al., 2009, p. 1836), as he witnessed two world wars. He drew attention to the society 
of his time and "the universal human conflicts between art and life, sensuality and intellect, individual and social will” (Lawall, et al., 2009, p. 1837).

The philosopher Arthur Schopenhauer (1788-1860) influenced Mann "for his vision of the artist's sufferings and development" in addition to the philosopher Friedrich Nietzche (1844-1900) "for his portrait of the diseased artist overcoming chaos and decay to produce, through discipline and will" and the composer Richard Wagner (1813-1883) in the way of becoming "a complete artist who controlled all aspects of his work: music, lyrics, the very staging of his operas" (Lawall, et al., 2009, p. 1837). Thus, considering such an intellectual background, it is not surprising for Mann to become a successful writer. His modernist novella Death in Venice (1912) is regarded as his masterpiece "displaying the penetrating detail of his social and psychological realism, the power of his tightly interwoven symbolic structure, and the cumulative impact of his artist-hero's fall” (Lawall, et al., 2009, p. 1837). Therefore, it may be regarded as the creation of his strong artistic background.

Mann wrote Death in Venice after a short trip with his wife and brother to the city where he was fascinated by a Polish boy whom he saw playing next to the beach just as the protagonist of the work does. It was this "personal and lyrical experience" which prompted him to write his preeminent novella and it is Mann's semi-autobiographical work about which he notes in $A$ Sketch of My Life: "Nothing in Death in Venice is invented: the traveller by the Northern Cemetery in Munich, the gloomy boat from Pola, the aged fop, the dubious gondolier, Tadzio and his family, the departure prevented by a mix-up over luggage, the cholera, ..., or whatever else you might care to mention..." (1961, p. 296). Even the name he gives to his protagonist has a background for Mann. The character's first name derives from the Austrian composer Gustav Mahler (1860-1911), who died when Mann was on his vacation in Venice while the last name "Aschenbach" comes from Andreas Aschenbach (1815-1910), a German painter who "broke with the romantic tradition of painting landscapes" signalling the author's desire to abandon Wagner's influence (Mundt, 2004, p. 87). The artistic derivation of the names reveals the protagonist's Dionysian self which is, indeed, repressed by German culture and burst out in Venice. The surname "Aschenbach" meaning "Ashbrook" has "connotations of exhausted fires, of a stream gone dry, and of the aftermath of cremation" (Koelb, 2004, p. 96). Accordingly, it refers both to "death" and the canals of Venice. It is obvious that the choice of the names for the protagonist goes hand in hand with the Venice that is represented as a city of death.

As noted by Koelb, in Death in Venice, Mann made use of the narrative technique called "free indirect style," which he learnt from Gustave Flaubert efficiently. The story of the novella is told from the perspective of a third-person character whose voice cannot be distinguished 
from the protagonist's voice as it delves into his mind freely (2004, p. 102). Thus, the chosen narrative style contributes to the reflection of the precarious state of the protagonist throughout the work.

The novella revolves around Gustav von Aschenbach, in his fifties and suffering from a lack of creativity and physical strength, and his trip to Venice where he falls in love with a Polish boy called "Tadzio" and then dies of cholera. Setting Aschenbach's story in Venice has significance for Mann because, on one hand, we have the protagonist suffering from many conflicts; of rationalism and sensuality, of his background shaped by German discipline and restrictions he wants to overcome, of his love for Tadzio and his intention of leaving Venice. On the other hand, we have Venice, which has magical power attracting tourists by means of its being comprised of two contrasting cultures; Eastern sensuality and Western rationalism, and known as a city of decay, hypocrisy and corruption. In his letter to Weber, Mann noted that he aimed at "an equilibrium of sensuality and morality" in Death in Venice, which is both "irresponsible and individualistic" and "morally and socially responsible" (2002, pp. 102-103, qt. in Mundt, 2004, p. 98). The contradictions of the city go hand in hand with the conflicts of the protagonist in the novella. Venice becomes the image of Aschenbach's inner crisis in a mirror held up to him. Thus, the aim of the paper is to examine the parallels between the mindscape of the novella's protagonist, Gustav von Aschenbach, and Venice as a Dionysian city in geographical and cultural contexts, overwhelming the character psychologically and physically.

\section{Munich versus Venice as an alluring space}

The city of Venice lies in the north-eastern part of Italy, a key nexus in the trade routes between Asia and Europe, blending the sensual and exotic nature of the East and restrained "civilized" Europe. It is composed of 118 islands, which are separated by canals and combined with bridges. It was in the seventh century that the city was originally founded by the Romans who had escaped from Germanic invasions in the fifth century, and extended and strengthened the neighbouring islands (Robertson, 2004, p. 98). In the $10^{\text {th }}$ and $11^{\text {th }}$ centuries, due to its geographical location, commercial relations with the Byzantine Empire influenced Venice's speed of urbanisation. Venice became identified as the "safeguard to the West, the pathway to the gorgeous East" and found charming because of its wealth obtained from the coveted silk and spice trade routes. Its connections with the Byzantine Empire provided the city both with wealth and gorgeous architecture, which is a blend of Western and Eastern styles (Plant, 2002, p. 41). 
In addition to its Oriental nature, Venice has been a city of dreams attracting many travellers, tourists, and, especially, artists with its colourful buildings, houses, canals, carnivals and a mystical atmosphere with magnetic power over the ages. It has been mentioned in various literary works of significant authors such as Shakespeare, who used it as a setting in plays such as Romeo and Juliet (1597) and The Merchant of Venice (1605). Pointing out the alluring nature of the city for various authors of European literature, Stevens states: "[Ralph Waldo] Emerson [1803-1882] wanted to love it [Venice]. [Lord] Byron [1788-1824] could not stop. [Ann] Radcliffe [1764-1823] used its image without ever having known the pleasure in person, while [John] Ruskin [1819-1900] methodically studied every inch of its stony face" (2010, p. 1). In the Dionysian understanding, it is home both to enthusiasm, thrill and sexuality. In 1892, the English poet, John Addington Simonds (1840-1893) went to Venice where he was finally able to express his homosexuality away from the strictures of England and his marriage. As noted by Tobin, for Germans of the $20^{\text {th }}$ century, Italy was a place to feel free from restrictions on homosexuality. Venice was especially a vacation centre for homosexuals (1994, p. 209). For instance, it was a place for Johann Wolfgang von Goethe's (1749-1832) erotic discoveries. Johann Joachim Winckelmann (1717-1768) also preferred leading the rest of his life there freely (Tobin, 1994, pp. 209-210). Considering both the author's and the protagonist's homosexual identity, the Dionysian nature of Venice seems to allure people. On the other hand, it presents chaos, ecstasy and drunkenness to its visitors whom it strangles with its deepness and complicatedness. The opening lines of one of August von Platen's (1796-1835) Venetian poems, "Tristan" (1825), brings Venice in relation to beauty and death. In addition, Henry James (1843-1916), a passionate author about Venice, notes: "It is a fact that almost everyone interesting, appealing, melancholy, memorable, odd, seems at one time or another, after many days and much life, to have gravitated to Venice by happy instinct," (1909, p. 115) and he adds, "the deposed, the defeated, the disenchanted, the wounded, or even only the bored, have seemed to find there something that no other place can give" (1909, p. 115). One of the reasons for its association with death is the lagoon extending from the northern edge of Venice called "laguna morta" meaning 'dead lagoon'. In this lagoon, there is a cemetery island called San Michele and a haunted house called "Casa degli Spiriti" on the northern edge of the city. This region formed by the "dead" lagoon, the cemetery island, and the northern edge of the city creates the image of a death zone. Furthermore, the collapse of the Republic of Venice in 1797 was also followed by a long period of political and economic decline. Accordingly, figuratively speaking, Venice itself is dead. The city, lying on the lagoon, sinks back a little farther into its swampy surroundings every year. Thus, in Dionysian thought, literarily, it is the site of 
corruption. When all its colourful and artificial buildings are removed from the city, a mere lagoon is left, that is, corruption and death concealed behind artificiality, just like the masks worn in the carnivals held in Venice.

Venice stops being a mere setting in Death in Venice because it acts as a character throughout the work influencing the protagonist who visits it. The impact of the city upon Aschenbach is enforced by his background constructed by Munich where Apollonian principles dominate. It is an Apollonian city with orderly and uniformly built buildings and people following the same routines in their daily lives. Considering the fact that the work was written after the industrial revolution in the early $20^{\text {th }}$ century when Germany was one of the global powers and produced middle-class people who sought to sustain a hypocritical way of life and deny the subconscious urges of the human psyche. The classicism of Northern Europe is contrasted with the romanticism of Southern Europe with its commitment to discipline, selfrestraint and order.

As a product of his German culture which is shaped by Apollonian features, Aschenbach leads a preset and monotonous life. Indeed, he does not desire but feels obliged to lead this way of life. Thus, while leading a life driven by Apollonian forces, Aschenbach suppresses his Dionysian nature. His motto is "Persevere" (Mann, 2004, p. 14). Aschenbach is the son of a civil servant and the "self-discipline he had practiced from an early age" (Mann, 2004, pp. 7-8) derives from his family, and endurance has left no space for "sloth, the carefree, laissez-faire attitude of youth" (Mann, 2004, p. 13). However, what he is, indeed, required to "preserve" is his psyche by building a harmony between his Apollonian self and the Dionysian one. He was "preoccupied with the tasks imposed upon him by his ego and the European psyche" (Mann, 2004, p. 7). That Aschenbach cultivates himself with some Apollonian enforcements isolates him from his environment.

His works are also the products of his society, consisting of "the utmost caution, prudence, tenacity and precision of will" (Mann, 2004, p. 1). They are described as "exemplary, polished and conventional, conservative, formal and even formulaic" (Mann, 2004, p. 2). He is a reputed national author whose works are read in schools so that schoolboys may be inspired by him. He favours and seeks to imitate the order, balance and restraint considered to be characteristics of classical literature (Robertson, 2004, p. 97). Thus, both his life and works are closely parallel with the Apollonian principles. However, his art lacks in Dionysian elements; thus, new energy for creativity is suppressed by cultural norms as he has "subjected his feelings, cooled them and enslaved them" (Ezergailis, 1975, p. 51) with Apollonian forces. His homosexuality is publicly accepted to be immoral in German culture. Therefore, preoccupied 
with the classical ideals of male beauty, Aschenbach becomes fascinated with the Venetian statues surviving from the ancient world as they evoke his repressed sexual desires (Robertson, 2004, p. 96). Even in the Spartan setting of Germany, surrounded by mountains, among peaks and high walls, encouraging isolation and discouraging access and control from the outside may be associated with the male principles of Apollon, while Venice's exotic atmosphere evokes female principles of Dionysus (Ezergailis, 1975, p. 51). Venice is as chaotic as Aschenbach's mental state. It casts the role of Aschenbach's mental landscape which is like a battleground of Apollonism and Dionysianism. Similarly, Venice is the blend of sea and land, constructed on tepid, miasmic swamps. It is half-classic and half-romantic, on one hand the site of architectural magnificence, on the other hand corruption and degradation, in the narrator's words, "half fairy tale, half tourist trap" (Mann, 2004, p.104). Venice is, as the narrator refers to, the "most improbable of cities" (Mann, 2004, p. 34), which is totally in contrast to Münich for Aschenbach.

Indeed, [h]is attraction to Venice underlines his Romantic leanings" (Robertson, 2004, p. 98). He regards the city as a "stunning composition of fantastic architecture," (Mann, 2004, p. 34) "the ethereal splendour of the Palace and the Bridge of Sighs, the waterside columns with lion and saint, the majestically projecting flank of the fairy-tale basilica” (Mann, 2004, p. 34). The narrator describes Venice's beauty as "seductive" (Mann, 2004, p. 55). Therefore, it is the best setting for Mann to portray Aschenbach's tale of love and death, beauty and sickness in a novella, which is "a densely written exploration of the contest between mutually opposed forces - between fertility/decay, passion/dignity, North/South, impulse/repression and conventionality/transgression (Brinkley, 1999, p. 4). As a character whose Apollonian features are overshadowed, Venice plays the Dionysian role of sensuality, disorder and liberation that brings demise to the protagonist.

The narrator describes Venice as "[a] city irresistible to the man of culture for both its history and its current charms" (Mann, 2004, p. 27); however, Aschenbach is a northerner and, to Northerners, Venice represents "[b]eauty, [f]ear and [d]eath" (Leppmann, 1975, p. 66). Therefore, the narrator characterizes it as a sinister figure with its "repellent sultriness" (Mann, 2004, p. 62) and "fetid effluvia" (Mann, 2004, p. 63), thus, a Dionysian character which hinders Apollo from entry. It behaves as "a liberator" (Paglia, 1990, p. 48) enabling Aschenbach to set his repressed side free by stopping his Apollonian self. Accordingly, Venice is portrayed as a paradoxical city, where "death is feared or pursued, cherished and enacted in the decay of splendor, in the excess and corruption of beauty...in the ambivalence of sensual, mental elation 
and a lugubrious atmosphere of doom" (Perosa, 2003, p. 281), and Aschenbach seems to be doomed to this paradox.

There are some Dionysian messengers throughout the work, each of whom has a mysterious and convincing impact advancing Aschenbach's journey to internal dissolution (Bloom, 2003, p. 15). Firstly, he encounters an unknown red-haired male traveller outside a stonemason's yard full of funerary monuments. The strange man had a yellowish face, the colour of which may be associated with the idea of death, had a "distinct foreign, exotic air" (Mann, 2004, p. 4) and "his lips seemed too short; they pulled all the way back, baring his long, white teeth to the gums" (Mann, 2004, p. 5) This traveller enticed Aschenbach into "a fervent youthful craving for faraway places" (Mann, 2004, p. 5), containing "beds of thick, swollen and bizarrely burgeoning flora...stagnant, shadow-green, looking-glass waters...stoop-shouldered birds with misshapen beaks... the eyes of a crouching tiger" (Mann, 2004, p. 6). According to Robertson, these images suggest chaos, disorder, temptation, sexual power and even sexual violence - the complete opposite of the apparently "solid edifice of Aschenbach's professional life" (2004, p. 100). It ultimately results in "terror and an enigmatic craving" (Mann, 2004, p. 6) feelings suggesting ecstatic revelry, which is both terrifying and seductive, allowing for the first manifestation of Dionysus in Aschenbach's life.

Secondly, Aschenbach discerns a queer "scruffy sailor" (Mann, 2004, p. 13) leading him to the ticket seller to buy a ticket to Venice. Then, Aschenbach encounters an old, drunken fop with excessive make-up on his face while his boat is disembarking. He suggests homosexuality with "the tip of his tongue around the corners of his mouth in an obscenely suggestive manner" (Mann, 2004, p. 16). The last strange character is the strong gondolier who dominates the Apollonian nature of Aschenbach by taking him to a different destination and advances him to let his all restraint fall away including his suppressed homosexuality. "The smartest thing to do was to let matters take their course; more important, it was also the most pleasant" in the narrator's words (Mann 19). The "coffin-like" gondola that Aschenbach travels by suggests death. The gondolier also evokes the image of Charon who is the ferryman in the service of King Hades in Greek mythology. Charon takes the souls of the dead to Hades, the underworld, via the River Styx. Similarly, the gondolier takes Aschenbach to the destination he will die in - the Adriatic Sea, which represents the River Styx (Koelb, 2004, p. 101). Thus, the image may also be interpreted as a Dionysian message of death waiting for him in Venice. This voyage represents Aschenbach's departure from the Apollonian, the realm of rationality, knowledge and sobriety, to the Dionysian, the realm of intoxication, chaos, drunkenness, and death (Mundt, 2004, p. 93). 
Dionysus grips Aschenbach through the Polish boy, Tadzio, who stands for "the lure to the depths of Aschenbach's fall and degradation" (McWilliams, 1966-67, p. 24). As Ganguly notes, "the sultry Venetian setting incites Aschenbach's homoerotic passion for Tadzio, a beautiful god-like youth" (2018, p. 2) Identifying him as "godlike" (Mann, 2004, p. 85) and resembling noble Greek sculptures, specifically Spinario (Boy With Thorn), which is an ancient sculpture known for its classical model of beauty, Aschenbach is fascinated by Tadzio. His initial attractiveness with his sculpture-like body is associated with Apollonian art. Afterwards, Aschenbach is wrapped up with the Dionysian, thus, the sensual fascination with Tadzio. The musical nature of Tadzio's name which he describes as "almost like a catchword, its soft consonants and long-drawn-out final 'u' making it at once sweet and wild" (Mann, 2004, p. 60) fascinates him. Music appeals to the listener's emotions; thus, it suggests Dionysianism. Therefore, Tadzio evokes both the Apollonian and Dionysian sides of Aschenbach. In the embodiment of Tadzio, Venice gradually beguiles him. Put differently, the Dionysiac city appears to lure Aschenbach into self-abandon.

From Nietzsche's perspective, Aschenbach is expected to make use of the excitement he derives from his inspiration source to create his highly skilled art by combining it with his Apollonian principles. Tadzio's beauty makes Aschenbach unlock the door of the inspired art he tries to keep locked up so as to go on writing within the framework of standard art. The reason is that it has been the Apollonian art favoured by German readers, thus, his works have been admired, and he has been given the title "von" in Munich. However, he has never been happy with that title, and he feels sick with the lack of creativity because his lifelong act of repressing his Dionysian side in order to practice his art causes an increasing lack of capacity for his Apollonian perfectness of self-control to realize his art form, and now it is time for him to follow the way of inspired art with the energy he has got from Tadzio. He feels like going on writing without any restrictions or rules. Therefore, he follows wherever the boy goes. He watches Tadzio on the beach "clad in white and with a bright-colored sash... seeing Hyacinth who loved by two gods, was doomed to death" (Mann, 2004, p. 92). It is obvious that the Venetian landscape presents Tadzio to him as a stimulating object. He feels like writing and then composes his most sublime prose even though it is his last artistic product of a half page long. However, while observing Tadzio from afar, Aschenbach becomes interested in "his legs beating the resistant water into foam, his head flung back, and to see so vibrant a figure, with the grace and austerity of early manhood, locks dripping, fair as a gentle god, emerging from the depths of sea and sky, escaping the watery element" (Mann, 2004, p. 60). Thus, Tadzio, as an object of desire, both aids and hinders Aschenbach's creativity, and it is obvious that the 
Apollonian nature dominating him in Munich is beingdefeated by the Dionysian part of his self. He senses a "decline in...stamina" in which he is "overstimulated by many hours of difficult work, full of pitfalls....and demanding probing insistence (Mann, 2004, p. 139).

Because of its swamp and cholera spreading in the city like an invisible "deadly" fog, "the former queen of the seas [Venice] has fallen victim to a petty and predatory commercialism" (Ganguly, 2018, p. 4) just like Aschenbach who is a once-great author in Germany but is then defeated by excessive Dionysian self in Venice. Thus, the cholera epidemic said to have originated in India spreading "with unwonted virulence through Hindustan, then moved eastwards to China...several Mediterranean ports" (Mann, 2004, p. 120), is of Asian origin like Dionysus, who is described as a "dark god whose pleasure it is to trample man's intoxicating rapture and chaos" (Mundt, 2004, p. 91). Cholera contextualizes the intangible force of Dionysus within Aschenbach. Accordingly, both because of cholera and the Dionysian nature in Venice corrupting his Apollonian self, he feels "dizzy spells that were only partly physical" (Mann, 2004, p. 138). His feelings suggest that Aschenbach's predominating Dionysian side results in oscillation and conflict with the Apollonian part of his nature.

The Dionysian-like danger of the Venetian city, cholera, is hidden beneath its magnificent appearance. Therefore, the once preeminent city as "the sunken queen" (Mann, 2004, p. 64) turns out to be a "diseased city" (Mann, 2004, p. 101) with its sultry atmosphere. The rain and oppressive air in the Venetian midsummer make Aschenbach feel unwell "through the murky labyrinth of the canals under graceful marble balconies flanked by... past funeral palazzo façades" (Mann, 2004, p. 64). The allusion to the labyrinth evokes a perilous space from which there is no escape for Aschenbach, who becomes a helpless slave of the Venetian city. After failing to reclaim his luggage to go back to Munich, he returns to the hotel and completely surrenders himself to the control of his Dionysian side. He becomes identical with Venice where the disease cholera is kept as a secret so as not to frighten the tourists and lead to financial loss. Similarly, Aschenbach keeps his love for Tadzio secret and decides not to tell Tadzio's family about the disease so that they do not leave the city. Therefore, Aschenbach becomes as selfish as Venice, and they are both doomed to decay. When he learns about the epidemic disease, he finds it exciting rather than frightening as much as his passion for Tadzio. The excitement of the plague starts to spread all through the city indicating "every loosening of the fabric of society" (Mann, 2004, p. 100), similar to the strict German rules that Aschenbach has once embraced because it is a "nasty secret [which] had merged with his own innermost secret" (Mann, 2004, p. 100), his love for Tadzio, for Aschenbach. Aschenbach is as frail and “diseased" (Mann, 2004, p. 101) as Venice. 
Walking from the beautiful beaches of Lido to the narrow, dark and smelling streets, Aschenbach sweats uncomfortably and confronts the horrible face of the city at the same time. His vision begins to be blurred, he feels the blood pound in his head as the physical manifestations of the protagonist's damaged mental state. The beggars disturb him in the poorer area, and the "evil emanations" (Mann, 2004, p. 155) from the canals hinder his breathing. It is obvious that Aschenbach's self-destruction, the dispersion of his self-control, the suffering in his mind, his conflicts all go hand in hand with the portrayal of the city, which is highly affected by the spread of cholera. Until returning to his hotel room, he is disgusted by "the foul-smelling lagoon" (Mann, 2004, p. 63) and the "noxious" air (Mann, 2004, p. 103). Aschenbach smells an "unusual aroma in the air" (Mann, 2004, p. 98) at San Marco and feels dizzy with the "cloying medicinal smell redolent of squalor and sores and dubious hygiene (Mann, 2004, p. 98).

In addition, the "Arabian lattices [which] showed shadowy in the gloom" (Mann, 2004, p. 115) recall both the east (Dionysus's origin) and even prison bars, suggestive of Aschenbach's transgression and captivity. Evidently, Aschenbach's mental and physical spaces correlate in accordance with the Dionysiac nature of Venice. It becomes apparent with his utterance of "I love you!" (Mann, 2004, p. 96) that Dionysian nature prevails over the Apollonian one. His total surrender to the Dionysian self is suggested by his dream of a wild crowd of worshippers around the statue of "the stranger god [Dionysus]" (Mann, 2004, p. 126). The narrator notes that Aschenbach belongs to the mentioned god (Mann, 2004, p. 128) as he becomes the slave of his overwhelming desire for Tadzio. When he acknowledges that Tadzio is about to leave Venice, his vision of the city totally changes. For him, "[a]n autumnal, offseason mood seemed to lie upon the once so colorful and animated, now all but deserted pleasure haunt, its sand no longer kept clean" (Mann, 2004, pp. 138-139). Shortly afterwards, he dies while watching the object of his desire, Tadzio, wrestling on the beach. His vision as "a young man in his prime" (Mann, 2004, p. 132) with grotesque make-up, eccentric dress in the hope of drawing Tadzio's attention reminds the reader of the Dionysian messengers, the fops, one of whom he has encountered early on at beginning of his journey while another he has seen in the role of guitar-playing singer in the musical entertainment in the hotel garden. Tadzio's defeat in wrestling on the beach where Aschenbach dies while watching him suggests Aschenbach's defeat by cholera, his love for Tadzio, overall by Dionysian Venice literarily and literally. Although he is celebrated as a masterful author, his visit to Venice makes him understand through Tadzio that his art has been insufficient as it is dominated by Apollonian principles. As noted by Webber, he "seems here to commit himself to the ultimate test of 
performing life through art" (2002, p. 77). He fails in his life and art as he cannot reconcile his Apollonian reason and his Dionysian passion.

\section{Conclusion}

Venice figuratively fits as a setting where the protagonist, who is a well-disciplined and principled German author, abandons the restraint side of his nature and gives voice to his sensuality, however, oscillating between his reason and sensuality. Aschenbach fails to create high-quality art by harmonizing his Apollonian principles with the inspiring landscape of Venice. Therefore, Dionysian Venice overpowers and consumes his Apollonian self, culminating in his dissolution. The study reveals that Venice acts as a considerably strong Dionysian character that potentially may lead those who cannot stabilize the harmony between the Apollonian and the Dionysian. In contrast to the protagonist's failure, the modernist author Mann achieves correlation of the contradictions of the city with Aschenbach's conflicts between his Apollonian and Dionysian selves Death in Venice. Venice becomes the image of Aschenbach's inner crisis in a mirror held up to him and acts as a Dionysian character deteriorating his condition and leading him to death.

\section{Works cited:}

Bloom, H. 2003. “Introduction.” In: Harold Bloom (ed.) Bloom's Major Short Story Writers: Thomas Mann. New York: Chelasea House Press, pp. 12-20.

Brinkley, E. S. 1999. "Fear of Form: Thomas Mann's Der Tod in Venedig." In: Montashefte, Vol. 91, No. 1, pp. 2-27.

Ezergailis, I. M. 1975. Male and Female: An Approach to Thomas Mann's Dialectic. The Hague: Martinus Nijhoff.

Ganguly, S. 2018. “Objective Correlative of Aschenbach's Repressed Self in Thomas Mann's Death in Venice.” In: IJCIRAS, Vol. 1, No. 4, pp. 1-5.

James, H. 1909. Italian Hours. Boston: Houghton Mifflin.

Koelb, C. 2004. "Death in Venice." In: Herbert Lehnert \& Eva Wessell (eds. and trans.) $A$ Companion to the Works of Thomas Mann. New York: Camden House, pp. 95-115.

Lawall, S. et al., (eds.). 2009. “Thomas Mann.” In: Sarah Lawall, et al. (eds.) The Norton Anthology of English Literature. New York \& London: Norton Company, pp. 1836-1840.

Leppmann, W. 1975. “Time and Place in Death in Venice.” In: The German Quarterly, Vol. 48, No. 1, pp. 66-75.

Mann, T. 2004. Death in Venice. (Trans. Michael Henry Heim). New York: HarperCollins. 
Mann, T. 1961. A Sketch of My Life. London: Secker \& Warburg.

McWilliams, J. R. 1966-67. "The Failure of a Repression: Thomas Mann's 'Tod in Venedig."” In: German Life \& Letters, Vol. 20, pp. 238-40.

Mundt, H. 2004. Understanding Thomas Mann. Columbia: University of South Carolina Press. Nietzsche, F. 1992. The Birth of Tragedy. Basic Writings of Nietzsche (Trans. Walter Kaufmann). New York: Modern Library, pp. 1-144.

Paglia, C. 1990. Sexual Personae: Art and Decadence from Nefertiti to Emily Dickinson. New Haven: Yale University Press.

Perosa, S. 2003. "The Wings of the Dove and the Coldness of Venice." In: The Henry James Review, Vol. 24, pp. 281-90.

Plant, M. 2002. Venice: Fragile City, 1797-1997. Yale University Press.

Robertson, R. 2004. "Classicism and Its Pitfalls: Death in Venice.” In: Ritchie Robertson (ed.) The Cambridge Companion to Thomas Mann. Cambridge: Cambridge University Press, pp. 95107.

Stevens, S. 2010. Venice As No-Place: Liminality and The Modernist Interpretation of The Myth of Venice. Oklahoma State University, PhD dissertation.

Tobin, R. 1994. "Why Is Tadzio a Boy?: Perspectives on Homoeroticism in Death in Venice." In: Clayton Koelb (ed. and trans.) Thomas Mann: Death in Venice: A New Translation, Backgrounds and Contexts, Criticism. London: W.W. Norton, pp. 207-32.

Webber, J. A. 2002. “Mann's Man's World: Gender and Sexuality.” In: Ritchie Robertson (ed.) The Cambridge Companion to Thomas Mann. Cambridge: Cambridge University Press, pp. 64-84.

Nilay Erdem Ayyıldız

Firat University

School of Foreign Languages

Üniversite Mah. 23200 Elazı̆̆/Merkez

Turkey

yalinmedre@hotmail.com/nerdem@firat.edu.tr 